\title{
Evaluation of the Heat Transfer Parameters and Their Influence on the Cooking Value in the Thermal Treatment Process of Tomato (Lycopersicon Esculentum Mill) Puree in Tin Container and Glass Container with White Cup
}

\author{
Sebastian A. Lozano-Ayala \\ Haydee S. Huanca-Apaza \\ David Vivanco-Pezantes \\ Faculty of Fishing and Food Engineering \\ University National of Callao \\ Peru
}

\begin{abstract}
The following experimental study analyzed the behavior from the free convective heat transfer in the pasteurized process of tomato puree to different concentrations in total solids, pasteurized temperature and container type, through the determination of the transfer parameters of convective heat. The variables tend to influence the dynamic in the convective currents and in the calorific capacity, the thermal process was given until reach the accumulative lethality of $P_{0}=1$ minute, securing the product harmlessness and evaluating the cooking value.An experimental design of 11 treatments by duplicated was established, for the study in tin and glass container. For last, from obtained results concluded the need to supply a pasteurized temperature near at $100{ }^{\circ} \mathrm{C}$ with a heating time that reach an accumulative lethality $P_{0}=1$ minute, where the total solids concentration has a non-significant influence, maintaining the nutritional and physical-organoleptic properties of the prime mater in the thermal treatment process.
\end{abstract}

Keywords: Thermal treatment, heat transfer by convection, cooking value, heat transfer speed, inertia factor, thermal diffusivity.

\section{Introduction}

Actually the food canned and heat treated for its conservation, present some limitations in its process, as submit them to high temperatures for long periods of times where bacterial reduction is sought, however this conditions are harmful because essential nutrients are affected producing alterations in the physics-organoleptic characteristics. This situation leads to analyze the behavior of the free convective heat transfer in a pasteurized process of tomato puree in tin container and glass container with white cup. Through the measurement of heat transfer parameters, quantifying the process to a determinate pasteurization temperature and total solids concentration from product. The behavior of the heat transfer parameters and cooking value, being this an analog value at microbial lethality value, will depend of the dimensions y calorific capacity in the containers, in addition of the variations during the thermal process that generate changes in the final quality of processed food (Lespinard, 2010), as the degradation in the carotenoids, is inhibited in part for the presence of amino acids as the Vitamin $\mathrm{C}$ present in the fruit, having a more retention of this nutrient when the process occurs at a shorter time and temperature (Melendez-Martinez, 2015).

Researches related to the problem analyzed is Highlighted as; Silva (1997), describes the optimization process in the pasteurization of fruits puree through the filling system in heat, through an empiric mathematical model, where highlights operative variables, the filling temperature and accumulative lethality process $\left(\mathrm{P}_{0}\right)$, evaluating the final retention of Vitamin $\mathrm{C}$, as quality evaluation factor, the influence of dimensioning container in the thermal retention process and the final quality product were highlighted, concluding that the cooling by refrigeration holds less vitamin $\mathrm{C}$ that the cooling by water, actually can determine thermal properties by way more effective through the use of computational software as the proposed by Alvis (2011), that making uses of a tool denominated DEPROTER 
(Determining of thermophiles properties) estimates thermophysical parameters based on thermal properties of the food facilitating the understanding of phenomena concerning a thermophysical property of food in thermal process.

\section{Materials and Methods}

The simple concentrated of tomato was used, for the studying of a semi solid fluid, where the behavior of the heat convective flows will depend of the total solids concentration, the nature convective from container and the pasteurization temperature in the thermal treatment system. The concentration ranges for the tomato paste, which corresponds to a process of simple concentration, is from 7 to $24 \%$ this range according normative Codex Alimentarius for tomato's concentrated (CODEX STAN 57-1981) obeys at puree. Relating to the pasteurized temperature was operated in a range of pasteurization between 70 to $100^{\circ} \mathrm{C}$, for the reduction of non-sporulated microorganisms present in a $\mathrm{pH}$ from 4.1 to 4.4, the last variable defined is the container type where was opted for process with glass container with white cup and tin container, because they are mostly in these presentations.

The prime mater comes of the north zone from country, was acquired of a local market from Callao. The glass container whit white cup is North American origin imported by the national company "Soluciones de Empaque S.A.C." and the tin container was manufactured by the national company "Metalpren S.A.C." The equipment were supplied by the Unitary Operations Laboratory of the Faculty of Fishing and Food Engineer at the University National of Callao, between which one mentions: An Electric vertical Autoclave from manufacturing national, a digital $\mathrm{pH}$ meter make HANNA instruments model HI8424, a Thermocouple temperature capture make RELES, a Digital scales, a Grams scales make AE ADAM model PW 254, a Manual seamer for tin container from manufacturing national, a Stainless steel support to the putting of signs to evaluate in the inside retort from manufacturing national, a Laptop make HP to register of temperature and calculation of accumulative lethality $\left(\mathrm{P}_{0}\right)$ in real time, a Refractometer make ATAGO model NAR-4T and an Stove make BINDER. In the pasteurized process of each experimental treatment, evaluated to different concentrations in the tomato puree and system temperature, evaluated the following parameters in the process of convective thermal transfer: heat transfer velocity $\left(\mathrm{f}_{\mathrm{h}}\right)$, inertia factor $\left(\mathrm{j}_{\mathrm{h}}\right)$, universal constant of heat transfer $(\mathrm{U})$ and the thermal diffusivity $(\alpha)$.Also calculated the cooking value $\left(\mathrm{C}_{0}\right)$ as measurement parameter in loss of protein quality in the prime mater. Should be noted that the pasteurized process occurred until reach a lethal value $\mathrm{P}_{0}=1$ minute, where secure the microbial inactivation. Under these estimations analyzed the influence of each parameter in the retention of the final quality of product to manufacture. In the calculation of the convective heat transfer parameters the use of established principles from the evaluation of progressive heating inside product for the heat transfer process of heater means to product was necessary. In the food thermal processing, la heat penetration curve is traditionally presented as $\log \left(\mathrm{T}_{\mathrm{M}}-\mathrm{T}\right)$ vs $\mathrm{t}$. this is shown in the graphic 1 , these parameters are considered in the operation of an autoclave (Orrego, 2003).

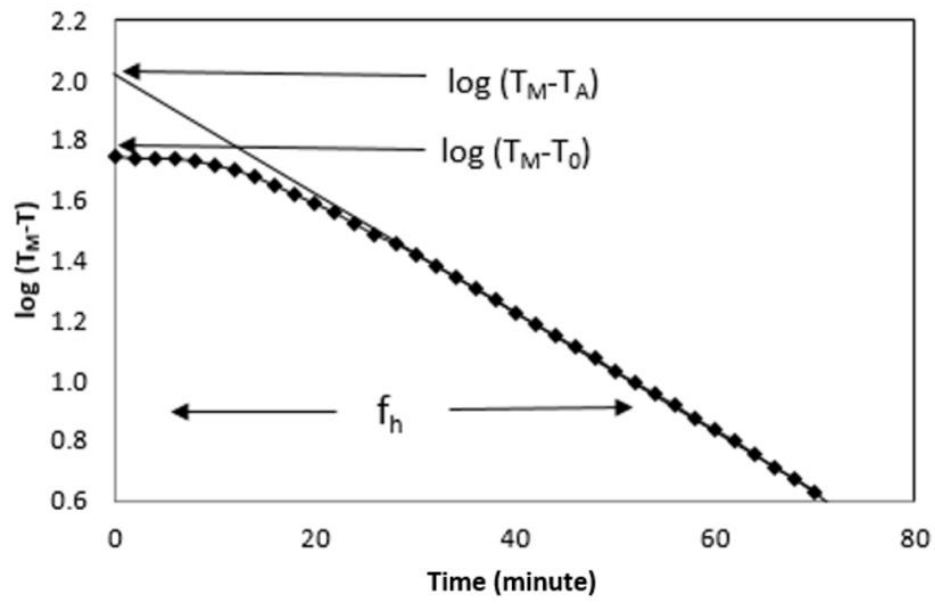

Graphic 1: Typical Graphic of a heating curve.

Of the graphic $1 \mathrm{~T}_{\mathrm{M}}$ is the inside temperature of system, $\mathrm{T}_{0}$ is the initial temperature of process, $\mathrm{T}$ is the temperature inside product and $\mathrm{T}_{\mathrm{A}}$ is the temperature pseudo initial of straight line extrapolated of the logarithmic curve, where deduced the following mathematical expression: 


$$
\log \left(T_{M}-T\right)=\log \left(T_{M}-T_{A}\right)-\frac{t}{f_{h}}
$$

Where the heating velocity value is an expression derived of the earring, correspondent at the straight extrapolated in the logarithmic curve, which increases when the food acquires calorific capacity in the thermal process. Of this analysis the inertia factor or convective delay in the process is established, as the logarithmic difference between the initial thermal assimilation in the process against estimated of the extrapolation that describes the time elapsed so that the coolest point from canned will reach the response line zone at the temperature $\left(\mathrm{f}_{\mathrm{h}}\right)($ Orrego, 2003), being established as the vector opposite to the thermal transfer velocity.

$$
\begin{gathered}
\log \left(T_{M}-T_{A}\right)-\log \left(T_{M}-T_{0}\right)=\log \left(j_{h}\right) \\
j_{h}=\frac{T_{M}-T_{A}}{T_{M}-T_{0}}
\end{gathered}
$$

Replacing the equation (2) in the equation (1), obtained the empiric equation for the heating process in unstable state of solidand semi-solidfoods canned.

$$
\log \left(\frac{T_{M}-T}{j_{h}\left(T_{M}-T_{0}\right)}\right)=-\frac{t}{f_{h}}
$$

The parameters $\mathrm{j}_{\mathrm{h}} \mathrm{y} \mathrm{f}_{\mathrm{h}}$, defines the penetration curve, these are estimated by experimental data's evaluation of "heat penetration" in the curve $\log \left(\mathrm{T}_{\mathrm{M}}-\mathrm{T}\right)$ vs t. Analyzing the heat transfer through the application of the general equation integrated of thermal balance and making use of global coefficient of convective thermal transfer $(\mathrm{U})$, the equation is described:

$$
m C_{p} \int_{T_{0}}^{T} \frac{d T}{\left(T_{M}-T\right)}=U A \int_{0}^{t} d t
$$

Where $\mathrm{m} \mathrm{y}_{\mathrm{p}}$ is the mass and specific heat respectively, of the prime matter and $\mathrm{A}$ is the surface area of heat transfer in the container, the equation 5 is reduced of the following way:

$$
\log \left(\frac{T-T_{M}}{T_{0}-T_{M}}\right)=-\frac{U A t}{m C_{p} 2.303}
$$

In effect, the equation integrated of thermal balance correspond in semi logarithmic coordinates, to a straight that pass by origin whoseearring is $1 / \mathrm{f}_{\mathrm{h}}$, establishing the following expression:

$$
f_{h}=\frac{m C_{p} 2.303}{U A}=\frac{V \rho C_{p} 2.303}{U A}
$$

One of the parameters that obtained whit the mentioned computational tools, is the thermal diffusivity $(\alpha)$ with which can calculate the mentioned concept $f_{h}$, which is fundamental for the design of thermal process. The relation between the diffusivity and the $\mathrm{f}_{\mathrm{h}}$ value in conductive heating, it represents in the following equation and reflects the effect of the containers dimensions, radio $(\mathrm{R})$ and height $(\mathrm{H})$.

$$
\alpha=\frac{0.398}{\frac{1}{R^{2}}+\left(\frac{0.427}{H^{2}}\right) f_{h}}
$$

One of the purpose of obtain the food thermal diffusivity of the heat penetration curve is precisely for making use of the heat penetration parameters $\mathrm{f}_{\mathrm{h}}, \mathrm{j}_{\mathrm{h}}$, etc., and with that simulate the canned food heat transfer. The advances that show the use of a simulator that basically has focused in the prediction of the time-temperature relation of product in any zone or point of container for different conditions process and for different sizes containers (WeltiChanes, 2005).

The behavior of the heat convective currents in a free or natural heat transfer system depend of the fluid nature, also of the temperature gradients inside product that generates the density difference inside, studies in the fluiddynamic in liquid and semi-solid foods are specified in figure 1. 


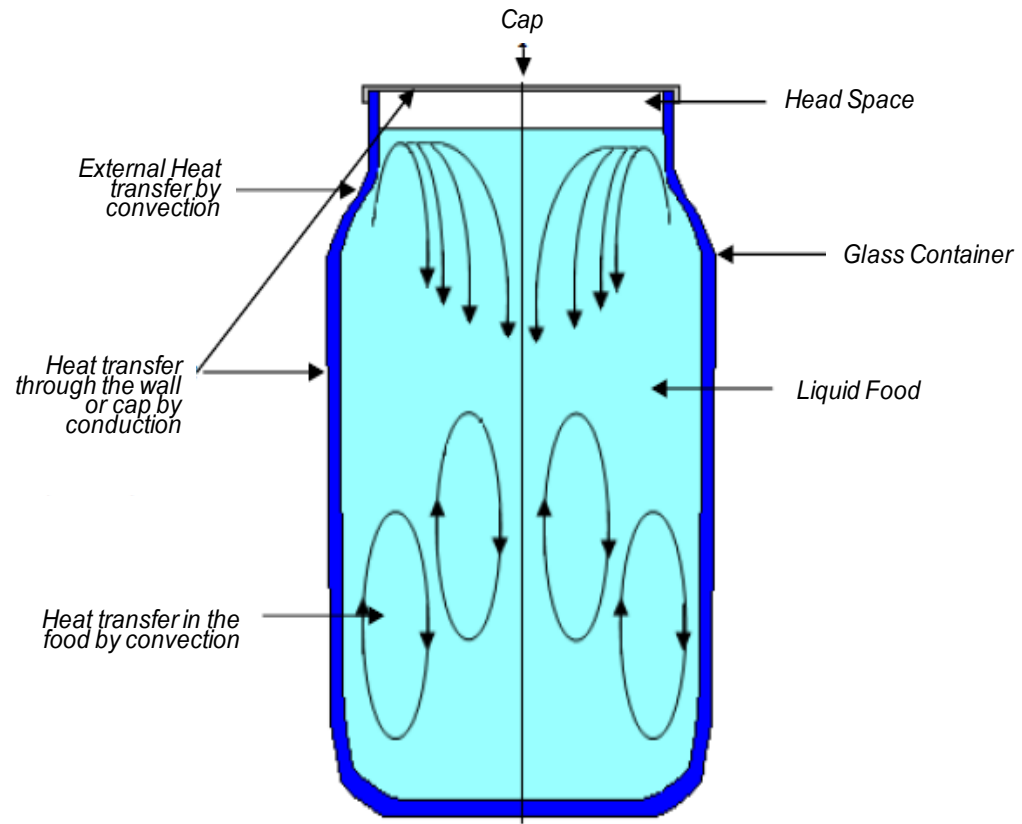

Source: Lespinard, 2010.

Figure 1: Convective Dynamic-Fluid in liquid foods.

The heat application during the thermal processing operation doesn't just cause microbial destruction and enzymatic inactivation, but also the nutrients degradation, texture changes (usually softening) and organoleptic disturbance. The final quality of canned product depends of the heat amount received. The biochemical reactions proceed substantially to a rate slower than the microbial inactivation, and this reflects in the high values of the decimal reduction temperature. The thermal treatment grade whit respect to these factors can reckon through the determination of cooking value $(\mathrm{C})$, whose equation is similarly at accumulate microbial lethality calculate $\left(\mathrm{F}_{0}\right)$ in the thermal treatment process (Holdsworth, 2007).

$$
C=\int_{0}^{t} 10^{\frac{T-T_{r e f}}{z_{c}}} d t
$$

Where $z_{c}$ is the analogous thermal destruction rate of $z$ value from microbial inactivation analysis and $T_{\text {ref }}$ is the referential temperature of thermal treatment, in the case of tomato puree treatment a $\mathrm{z}_{\mathrm{c}}$ of $21.6^{\circ} \mathrm{C}$ to a treatment $\mathrm{T}_{\text {ref }}$ of $93.3^{\circ} \mathrm{C}$ is used, in the evaluation of the biochemical stability from the tomato proteins (Williams, 1974).Of independent way is studied and analyzedeach one of the thermal transfer effects in the food a five levels of pasteurization temperature $\left(70^{\circ} \mathrm{C}, 74.4^{\circ} \mathrm{C}, 85^{\circ} \mathrm{C}, 95.6^{\circ} \mathrm{C}\right.$ y $\left.100^{\circ} \mathrm{C}\right)$ with threeconcentration levels in total solid $(9.47 \%, 15.5 \%$ y $21.5 \%)$ doing experiences by duplicated for glass and tin containers. These parameters were established from factorial experimental design with axial and centric points, shows in the table, determining for the calculating of the response surface in the optimization of thermal treatment process in the tomato puree in tin and glass container.

Table 1: Factorial experimental Design with centric and axial points.

\begin{tabular}{|c|c|c|c|c|}
\hline $\begin{array}{c}\text { Number of } \\
\text { Experimental Design }\end{array}$ & $\mathbf{X}_{1}$ & $\mathbf{X}_{2}$ & Concentration \% $\left(\mathbf{X}_{1}\right)$ & Temperature ${ }^{\circ} \mathrm{C}\left(\mathbf{X}_{2}\right)$ \\
\hline 1 & -1 & -1 & 9.47 & 74.4 \\
\hline 2 & 1 & -1 & 21.53 & 74.4 \\
\hline 3 & -1 & 1 & 9.47 & 95.6 \\
\hline 4 & 1 & 1 & 21.53 & 95.6 \\
\hline 5 & o & o & 15.5 & 85 \\
\hline 6 & o & o & 15.5 & 85 \\
\hline 7 & 0 & O & 15.5 & 85 \\
\hline 8 & -1.41 & o & 7 & 85 \\
\hline 9 & 1.41 & 0 & 24 & 85 \\
\hline 10 & 0 & -1.41 & 15.5 & 70 \\
\hline 11 & 0 & 1.41 & 15.5 & 100 \\
\hline
\end{tabular}


It should be noted that the thermal treatment time was established until reach a minim microbial lethality, which considering the allowable range of process accumulative lethality $\left(\mathrm{P}_{0}\right)$, established in $1.0-5.0$ minutes, $\left(\mathrm{T}_{\text {ref }}=\right.$ $\left.93.3^{\circ} \mathrm{C}, \mathrm{z}=8.3^{\circ} \mathrm{C}\right)$, (Eisner, 2010), thus the thermal process for each experience was only until reach a $\mathrm{P}_{0}=$ 1minute

\section{Results}

Of the thermal processing studies, the following convective thermal transfer parameters was obtained.
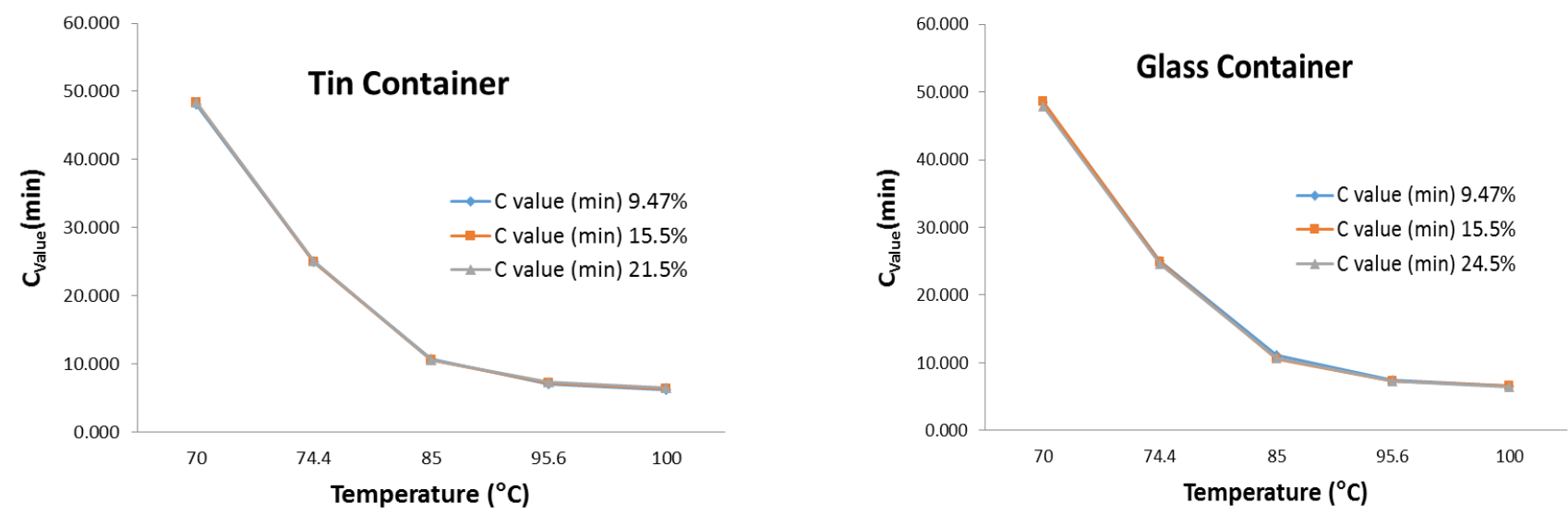

Graphic 2: Comparativeof Cooking Value at three concentration levels in total solids and five pasteurized temperature levels.
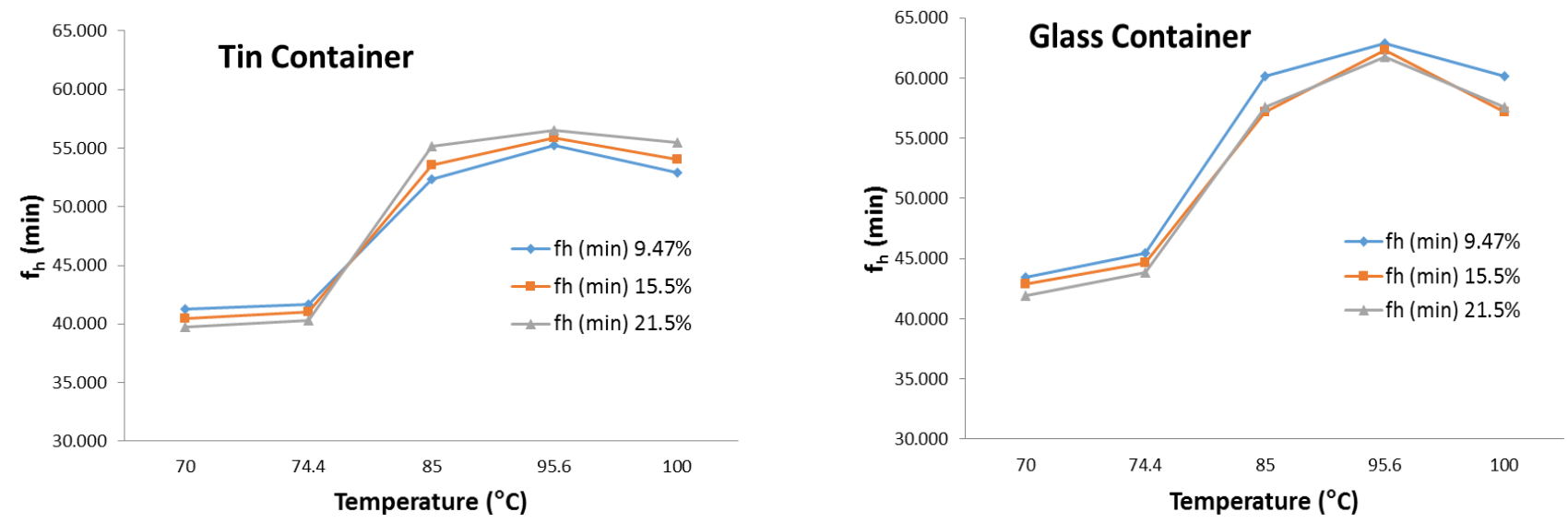

Graphic 3: Comparative ofHeat Transfer Rate at three concentrationlevels in total solids and five pasteurized temperature levels.
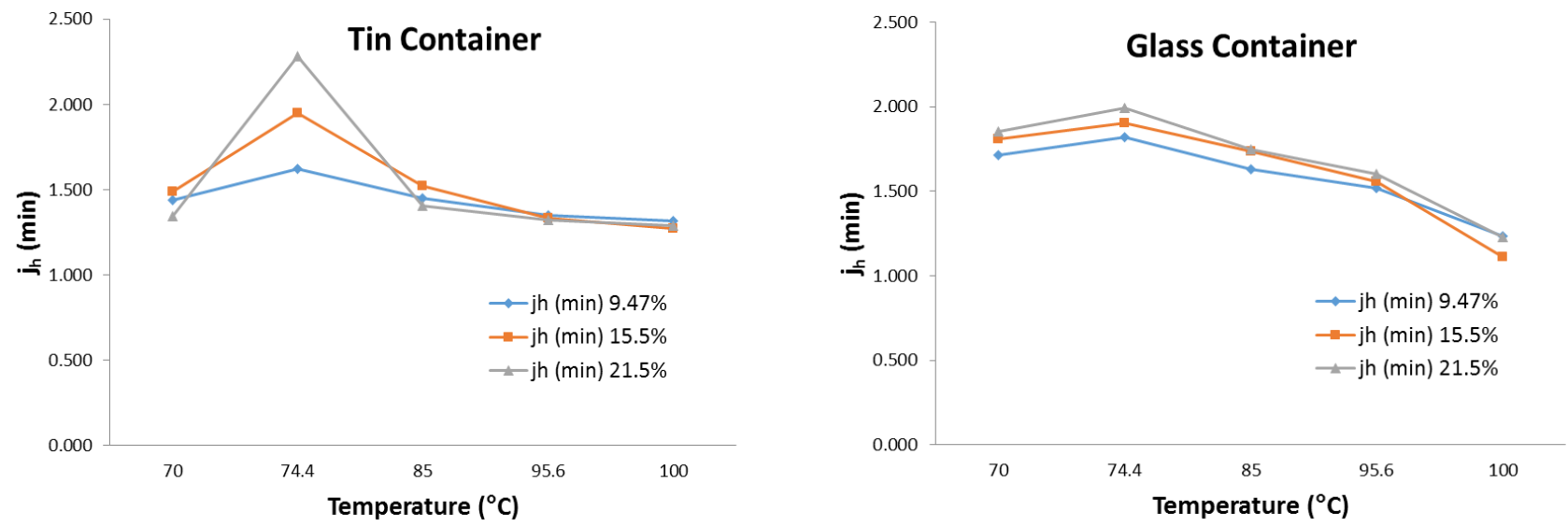

Graphic 4: Comparative of Inertia Factor at three concentrationlevels in total solids and five pasteurized temperature levels. 

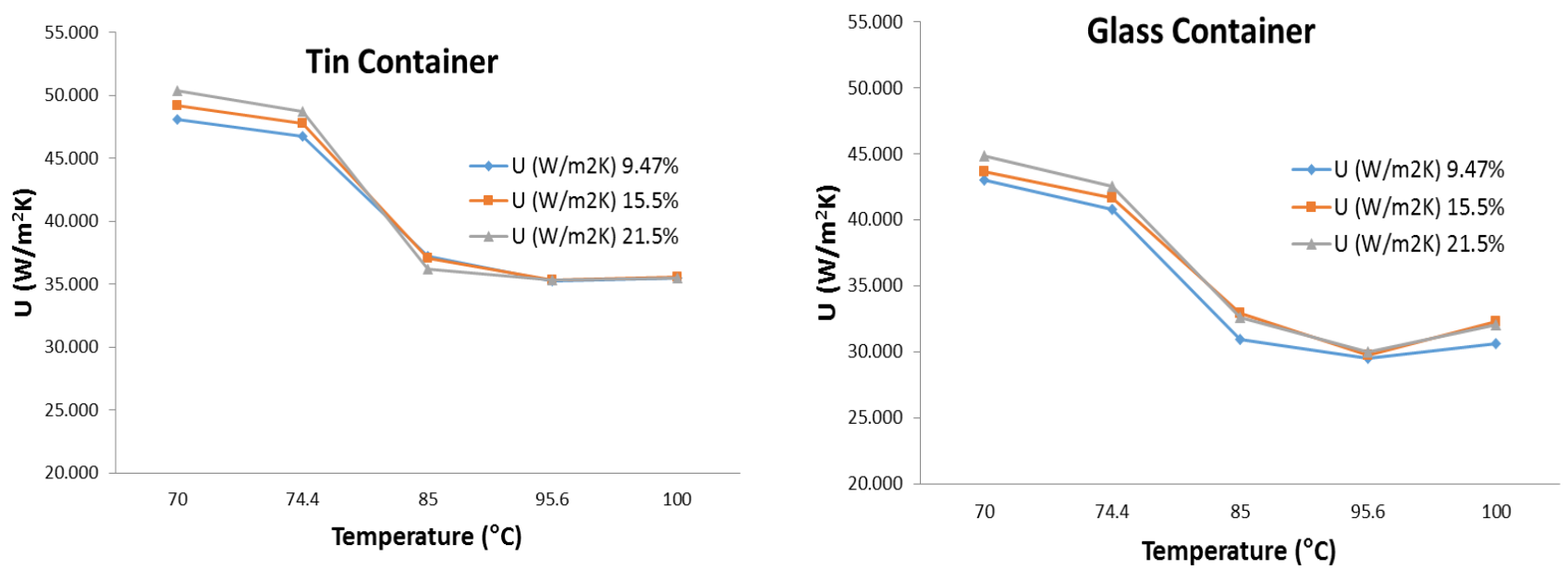

Graphic 5: Comparative of the Universal Constant of Heat Transfer at three concentrationlevels in total solids and five pasteurized temperature levels.
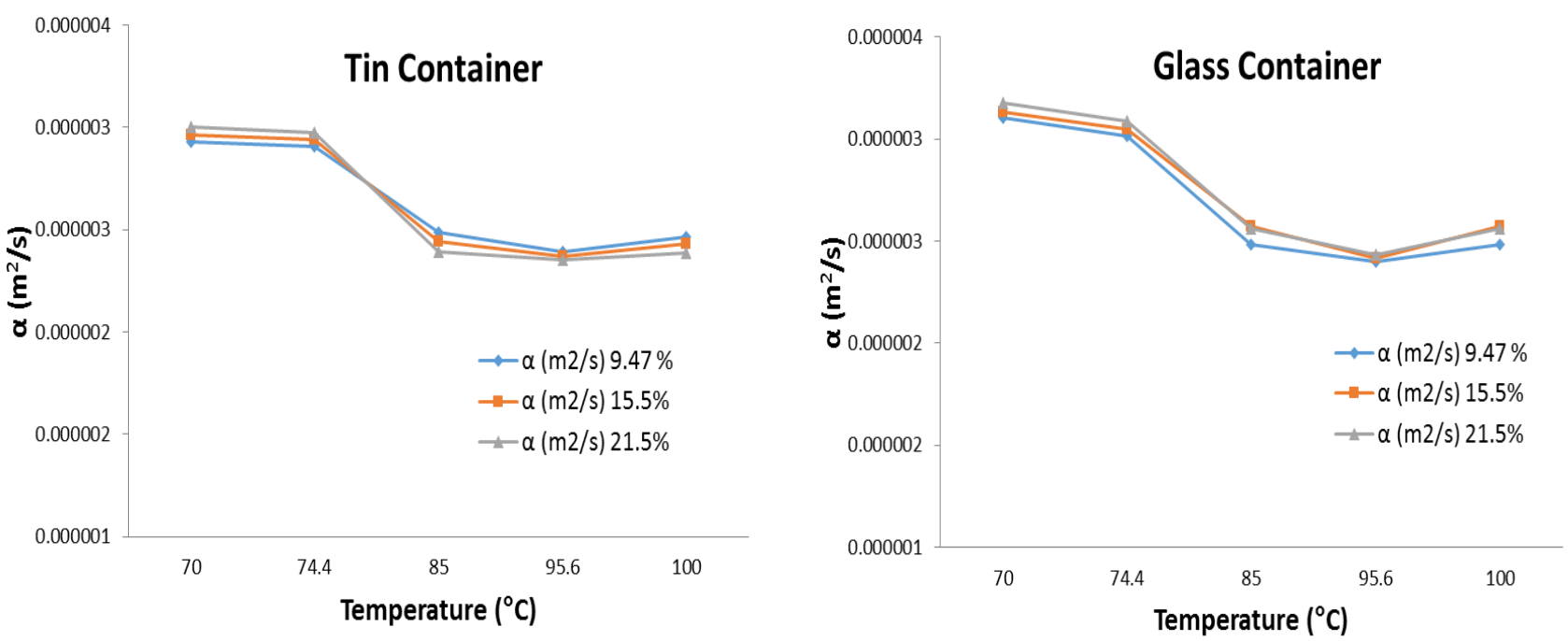

Graphic 6: Comparative of the Thermal Diffusivity at three concentration levels in total solids and five pasteurized temperature levels.

Regarding the cooking value, this present a logarithmic behavior similarly for both containers, determining that the nature of the container does not generate a significant influence on the nutritional and sensorial quality of the product, is reverse respect to the pasteurization temperature, because at lower treatment temperatures the product needs a longer pasteurization time to reach the $\mathrm{P}_{0}$ required, giving as result that the proteins and sensorial qualities tomato being exposed to the effects of convective heat currents. Also the concentration variation in the total solids does not influence in the alteration of this parameter.The inertia factor, as observe in the graphic has a reverse behavior to the pasteurization temperature, this behavior does not give itself in the heat transfer rate because greater pasteurized temperature narrows the time where the heat penetrates at thermal center of product. Also the container nature does not influence in the dynamic fluid principle and the total solids concentration affect of nonsignificant way in the thermal process.By last the parameters related to the process's calorific capacity (U, $\alpha)$ presents slight variations respect at container type used, the quantity of thermal resistant transmitted in the glass material is less in comparison at tin because to the thermal transfer constant between one material and another, however the quantity of heat diffused along the process is slightly more in the glass material because it was slightlyprolonged compared at tin material, having present that in the process was due to reach a accumulative microbial lethality $\mathrm{P}_{0}=1$ minute. 


\section{Conclusions}

Of the results determinate that the influence of the total solids concentration does not affect of significant way in the cooking value and at pasteurized time, however have a minim repercussion on the heat transfer diffusion where the forming of precipitates alters in a negligible way the convective flows in the fluid. There is less alteration of the proteins from prime mater during the thermal treatment process, when submit to a temperature of $92.4{ }^{\circ} \mathrm{C}$ for both container types that determine a shorter pasteurization process time and a lower calorific capacity, according to the measurement of cooking value. To increase the efficacy of thermal treatment process it is ideal to work with tin container at temperatures of $92.4^{\circ} \mathrm{C}$ and to concentrations near at minimum where the thermal transfer flow is greater, the dynamic fluid in the prime mater is stable and the calorific capacity is minimal, therefore, in addition to having a lower protein alteration, it results in a lower energetic consumption.

\section{References}

Holdsworth, D. \& Simpson, R. (2007). Thermal processing of packaged foods. Washington: Editorial Springer Science.

Holdsworth, D. (1997). Thermal processing of packaged foods. London: Editorial Chapman Hall.

Lespinard, A. R. (2010). Simulación y optimización del tratamiento térmico de alimentos envasados en recipientes de vidrio.(Thesis to opt the Doctor degree). University Nationalof La Plata, La Plata.

Melendez-Martinez, I. M. (2015). Estabilidad de los pigmentos carotenoides en los alimentos. Archivos latinoamericanos de nutrición. Volume (54): 2.

Ordoñez, L. (2006). Estudio comparativo de las características físico químicas, nutricionales y microscópicas de tomate (licopersicon esculentum mil.) procedente de cultivo ecológico y convencional, en fresco y tras la obtención de triturados, y de diferentes derivados comerciales de tomate. (Thesis to opt the Doctor degree). University from Santiago de Campostela, La Coruña.

Orrego, C. E. (2003). Procesamiento de alimentos. Manizales - Colombia: Editorial University National of Colombia.

Rodrigo, M. (Ed.). (1981). Optimización de las técnicas de esterilización por calor.Instituto de agroquímica y tecnología de alimentos. Volume(2): 20.

Rosero, D. (2007). Salsa de tomate.Colombia: University of Valle - Food Tecnology.

Sandoval, A. (Ed.). (1994). Prediction of hot-fill-air-cool sterilization processes for tomato paste in glass jars. Journal Food Engineering. Volume (23): 33 - 50.

Shafiur, M. \& Ahmed J. (2010). Food process desing. United Stated: Editorial Wiley-Blackwell.

Silva, F. (1997). Quality optimization of hot filed pasteurized fruit purees: container characteristics and filing temperatures. Journal of food Engineering. Volume (32): 351 - 364.

Tucker, G. (2010). Pasteurisation process desings. United Stated: Editorial Wiley-Blackwell.

Welti, J. (Ed.). (2005). Aplicaciones de ingeniería y fenómenos de transporte al estudio de la transferencia convectiva de calor en alimentos envasados. Revista Mexicana de Ingeniería Química.Volume(4): 89 106.

Williams, M. P. (Ed.). (1974). Kinetics of the thermal degradation of methylmethionine sulfonium salts. Journal Food Sci. Volume. (39): 457 - 460. 